\title{
Simultaneous monitoring of stable oxygen isotope composition in water vapour and precipitation over the central Tibetan Plateau
}

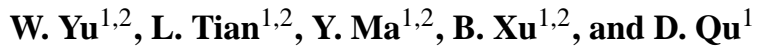 \\ ${ }^{1}$ Key Laboratory of Tibetan Environment Changes and Land Surface Processes, Institute of Tibetan Plateau Research, \\ Chinese Academy of Sciences, Beijing, China \\ ${ }^{2}$ CAS Center for Excellence in Tibetan Plateau Earth Sciences, Beijing, China
}

Correspondence to: W. Yu (yuws@itpcas.ac.cn)

Received: 22 February 2015 - Published in Atmos. Chem. Phys. Discuss.: 22 May 2015

Revised: 2 September 2015 - Accepted: 2 September 2015 - Published: 16 September 2015

\begin{abstract}
This study investigated daily $\delta^{18} \mathrm{O}$ variations of water vapour $\left(\delta^{18} \mathrm{O}_{\mathrm{v}}\right)$ and precipitation $\left(\delta^{18} \mathrm{O}_{\mathrm{p}}\right)$ simultaneously at Nagqu on the central Tibetan Plateau for the first time. Data show that the $\delta^{18} \mathrm{O}$ tendencies of water vapour coincide strongly with those of associated precipitation. The $\delta^{18} \mathrm{O}$ values of precipitation affect those of water vapour not only on the same day, but also for the following several days. In comparison, the $\delta^{18} \mathrm{O}$ values of local water vapour may only partly contribute to those of precipitation. During the entire sampling period, the variations of $\delta^{18} \mathrm{O}_{\mathrm{v}}$ and $\delta^{18} \mathrm{O}_{\mathrm{p}}$ at Nagqu did not appear dependent on temperature, but did seem significantly dependent on the joint contributions of relative humidity, pressure, and precipitation amount. In addition, the $\delta^{18} \mathrm{O}$ changes in water vapour and precipitation can be used to diagnose different moisture sources, especially the influences of the Indian monsoon and convection. Moreover, intense activities of the Indian monsoon and convection may cause the relative enrichment of $\delta^{18} \mathrm{O}_{\mathrm{p}}$ relative to $\delta^{18} \mathrm{O}_{\mathrm{v}}$ at Nagqu (on the central Tibetan Plateau) to differ from that at other stations on the northern Tibetan Plateau. These results indicate that the effects of different moisture sources, including the Indian monsoon and convection currents, need be considered when attempting to interpret paleoclimatic records on the central Tibetan Plateau.
\end{abstract}

\section{Introduction}

The Tibetan Plateau is a natural laboratory for studying the influences of different moisture sources, which include polar air masses from the Arctic, continental air masses from cen- tral Asia, and maritime air masses from the Indian and Pacific Oceans (Bryson, 1986), and for reconstructing paleoclimate variations (An et al., 2001). The stable oxygen isotope $\left(\delta^{18} \mathrm{O}\right)$ provides an important tracer for understanding atmospheric moisture cycling, especially by using the $\delta^{18} \mathrm{O}$ records in all three phases of water (Dansgaard, 1964; Lee et al., 2005). Oxygen isotopes also act as important indicators for reconstructing paleoclimates by using their records preserved in ice cores (Thompson et al., 2000), speleothems (Cai et al., 2010), tree rings (Treydte et al., 2006; X. Liu et al., 2014), and lake sediments (Zech et al., 2014). Variations of $\delta^{18} \mathrm{O}$ result from different isotope fractionation processes that may be influenced by temperature, humidity, and vapour pressure (Dansgaard, 1964; Jouzel and Merlivat, 1984; Rozanski et al., 1992), and from different moisture sources (Breitenbach et al., 2010; Pang et al., 2014).

To better understand atmospheric moisture transport to the Tibetan Plateau and surrounding regions, the Chinese Academy of Sciences (CAS) established an observation network in 1991 to continually survey $\delta^{18} \mathrm{O}$ variations in precipitation on the plateau (the Tibetan Plateau Network of Isotopes in Precipitation, TNIP) (Tian et al., 2001; Yu et al., 2008; Yao et al., 2013). Previous studies have shown that $\delta^{18} \mathrm{O}$ variations in precipitation on the southern Tibetan Plateau differ distinctly from those on the northern Tibetan Plateau (Tian et al., 2003; Yu et al., 2008; Yao et al., 2013). In addition, many scientists have investigated the roles of various climatic factors, especially the Asian monsoon's influence on $\delta^{18} \mathrm{O}$ in precipitation (Aizen et al., 1996; AraguásAraguás et al., 1998; Posmentier et al., 2004; Vuille et al., 2005; J. Liu et al., 2014; Yu et al., 2014a). Recent stud- 
ies have also investigated $\delta^{18} \mathrm{O}$ in river water (Bershaw et al., 2012), lake water (Yuan et al., 2011), and plant water (Zhao et al., 2011; Yu et al., 2014b). In comparison, only a few studies have focused on $\delta^{18} \mathrm{O}$ from water vapour over the Tibetan Plateau (Yatagai et al., 2004; Yu et al., 2005; Kurita and Yamada, 2008; Yin et al., 2008). Moreover, a gap exists in the studies regarding the relationship between $\delta^{18} \mathrm{O}$ of water vapour and of precipitation, and on the relative enrichment of $\delta^{18} \mathrm{O}$ from precipitation relative to that from water vapour over the Tibetan Plateau (In this study, the "relative enrichment" was defined as the difference of the $\delta^{18} \mathrm{O}$ values of precipitation $\left(\delta^{18} \mathrm{O}_{\mathrm{p}}\right)$ and vapour $\left(\delta^{18} \mathrm{O}_{\mathrm{v}}\right)$, $\left.\Delta \delta^{18} \mathrm{O}=\delta^{18} \mathrm{O}_{\mathrm{p}}-\delta^{18} \mathrm{O}_{\mathrm{v}}\right)$. An improved understanding of $\delta^{18} \mathrm{O}$ as tracers of water movement in the atmosphere and as indicators of climate change requires detailed knowledge of the isotopic compositions in all three phases of water (Lee et al., 2005). In contrast to liquid or solid precipitation, measurements of $\delta^{18} \mathrm{O}$ in water vapour can be taken across different seasons and synoptic situations, and are not limited to rainy days (Angert et al., 2008). Hence, $\delta^{18} \mathrm{O}$ in water vapour has become an important topic in the fields of paleoclimatology, hydrology (Iannone et al., 2010), and ecology (Lai et al., 2006), especially for understanding different moisture sources in order to describe different patterns of circulation and to evaluate water resources.

With this background, we launched a project in the summers of 2004 and 2005 to collect simultaneous water vapour and precipitation samples at Nagqu $\left(31^{\circ} 29^{\prime} \mathrm{N}, 92^{\circ} 04^{\prime} \mathrm{E}\right.$, $4508 \mathrm{~m}$ a.s.1.) on the central Tibetan Plateau (the first such study), despite the difficultly of collecting water vapour samples at this high elevation. Based on the $\delta^{18} \mathrm{O}$ data sets from these samples, this paper discusses the relationship between $\delta^{18} \mathrm{O}$ from water vapour and from precipitation, considers the effects of various meteorological parameters on the $\delta^{18} \mathrm{O}$ of water vapour and precipitation, and attempts to explain the relationships between the isotopic compositions of samples and moisture sources.

\section{Sampling sites, materials, and methods}

The Nagqu station lies in the middle of a short grass prairie, in a sub-frigid, semi-humid climate zone between the Tanggula and Nyainqentanglha mountains (Fig. 1). The annual average temperature at this station was recorded as $-2{ }^{\circ} \mathrm{C}$, with an annual mean relative humidity of $50 \%$, and average annual precipitation of $420 \mathrm{~mm}$. Most of the rainfall at this site occurred during May through August and accounted for about $77 \%$ of the annual precipitation.

This study collected water vapour samples at Nagqu during the periods of August-October 2004 and JulySeptember 2005. Based on an earlier study, if the condensation temperature falls below $-70^{\circ} \mathrm{C}$, the sampling method diminishes the correction factor $(-0.07 \%$ ) to below the typical error value quoted for ${ }^{18} \mathrm{O}$ analyses by modern mass

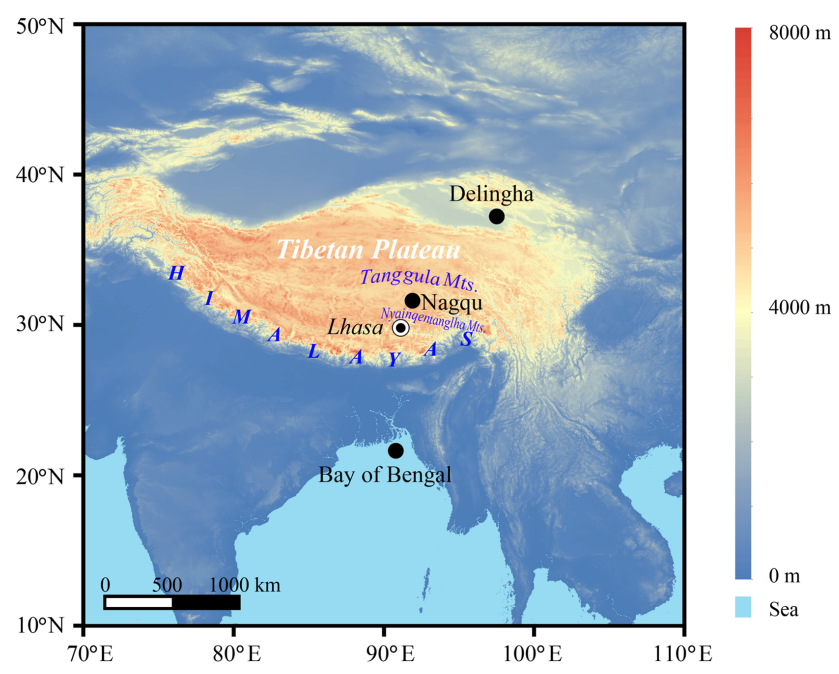

Figure 1. Map showing the sampling site at Nagqu on the central Tibetan Plateau, with the locations of the Delingha and Bay of Bengal stations, and the city of Lhasa.

spectrometers (Schoch-Fischer et al., 1984). Our study extracted water vapour cryogenically from the air, by pumping it slowly through a glass trap immersed in ethanol, which was continuously maintained at a temperature as low as $-70^{\circ} \mathrm{C}$ with a set of electric cryogenic coolers driven by a compressor (Yu et al., 2005). Thus the captured water vapour should precisely reflect the water vapour in the atmosphere and minimize fractionation during the sampling. Moreover, the cold trap was made in a linked-ball shape to increase the surface area for condensation (Hübner et al., 1979), and to ensure complete removal of all the water vapour, in order to avoid isotope fractionation during sampling (Gat et al., 2003). In addition, the validity of the cold trap operation was rechecked by connecting an extra glass trap to the outlet of the original trap. No visible condensed vapour was found within, reconfirming the validity of the water vapour sampling method. A flow meter controlled the air flow rate. For about $24 \mathrm{~h}$, air was drawn at a rate of about $5 \mathrm{~L} \mathrm{~min}^{-1}$ (Gat et al., 2003) through a plastic tube attached to the rooftop of the Nagqu station (the height of the roof is about $6 \mathrm{~m}$ ). At the end of each sampling, the two ends of the cold trap were sealed, and the samples melted at room temperature. Water was mixed across the trap before decanting it into a small vial and sealed. One sample of about $10 \mathrm{~mL}$ was collected each day. In addition, rainfall from each precipitation event at the Nagqu Meteorological Station (close to the vapour sampling site) was collected immediately and sealed in clean and dry plastic bottles. A total of 153 water vapour samples and 90 precipitation samples were collected. All the samples were stored below $-15^{\circ} \mathrm{C}$ until analysed. During the sampling period, some meteorological parameters, such as temperature at $1.5 \mathrm{~m}$, temperature near ground, relative humidity, surface pressure, and precipitation amount were recorded. 

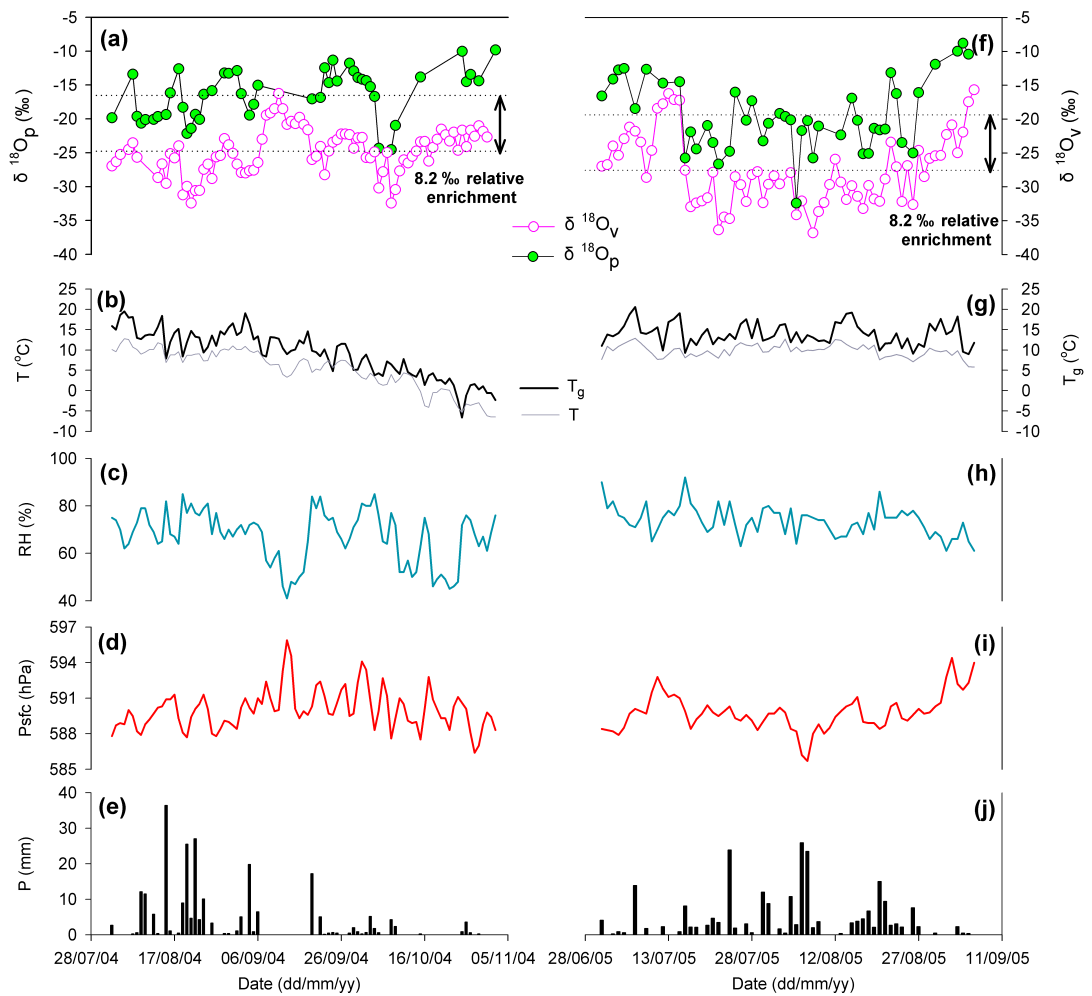

Figure 2. Daily variations of $\delta^{18} \mathrm{O}$ in water vapour $\left(\delta^{18} \mathrm{O}_{\mathrm{v}}\right)$ and precipitation $\left(\delta^{18} \mathrm{O}_{\mathrm{p}}\right)(\mathbf{a}, \mathbf{f})$, temperature at $1.5 \mathrm{~m}(T)$ and temperature near ground (at $\left.0 \mathrm{~m}, T_{\mathrm{g}}\right)(\mathbf{b}, \mathbf{g})$, relative humidity $(\mathrm{RH})(\mathbf{c}, \mathbf{h})$, surface pressure (Psfc) $(\mathbf{d}, \mathbf{i})$, and precipitation amount $(P)(\mathbf{e}, \mathbf{j})$ at Nagqu over the entire sampling period of 2004-2005.

The Key Laboratory of Tibetan Environment Changes and Land Surface Processes, Institute of Tibetan Plateau Research (Chinese Academy of Sciences, Beijing) performed the measurements of the oxygen isotopic compositions of all samples, using a MAT-253 mass spectrometer, with a precision of 0.2 parts per mil $(\% \circ)$ for the oxygen isotope ratios $\left(\delta^{18} \mathrm{O}\right)$. The $\mathrm{H}_{2} \mathrm{O}-\mathrm{CO}_{2}$ isotopic exchange equilibration method was adopted for the oxygen isotope ratios $\left(\delta^{18} \mathrm{O}\right)$ measurements. This study expresses the measured oxygen isotope ratios $\left(\delta^{18} \mathrm{O}\right)$ as parts per mil $(\% \circ)$ of their deviations, relative to the Vienna Standard Mean Ocean Water (VSMOW). Unfortunately, deuterium data at Nagqu were not available for this project.

To identify the moisture transport paths and interpret $\delta^{18} \mathrm{O}$ variability further in the time series, our study determined $120 \mathrm{~h}$ back trajectories for air parcels during the entire sampling period, using the NOAA HYSPLIT model (Draxler and Rolph, 1998) and NCEP reanalysis data sets (available at: ftp://arlftp.arlhq.noaa.gov/pub/archives/reanalysis). The origin of air masses as diagnosed from the back trajectory analysis appears to approximate the moisture source direction for the water vapour and for the precipitation at the study site (Guan et al., 2013). The trajectories originated at 1000, 2000, and $3000 \mathrm{~m}$ above ground level (a.g.l.), respectively.

\section{Results}

Figure 2 displays the daily changes of $\delta^{18} \mathrm{O}$ in water vapour $\left(\delta^{18} \mathrm{O}_{\mathrm{v}}\right)$ and in precipitation $\left(\delta^{18} \mathrm{O}_{\mathrm{p}}\right)$ at Nagqu. Clearly, the trends of $\delta^{18} \mathrm{O}_{\mathrm{v}}$ closely approximate those of $\delta^{18} \mathrm{O}_{\mathrm{p}}$ (Fig. 2a and f). A strong positive relationship existed between $\delta^{18} \mathrm{O}_{\mathrm{v}}$ and $\delta^{18} \mathrm{O}_{\mathrm{p}}$ during the entire sampling period of 2004-2005 $\left(\delta^{18} \mathrm{O}_{\mathrm{v}}=0.72 \delta^{18} \mathrm{O}_{\mathrm{p}}-14.43, r=\right.$ $0.81, n=86, p<0.01$ ) (Fig. 3). Moreover, the positive correlations between $\delta^{18} \mathrm{O}_{\mathrm{v}}$ and $\delta^{18} \mathrm{O}_{\mathrm{p}}$, whether in 2004 $\left(\delta^{18} \mathrm{O}_{\mathrm{v}}=0.73 \delta^{18} \mathrm{O}_{\mathrm{p}}-14.39, r=0.81, n=42, p<0.01\right)$, or in $2005\left(\delta^{18} \mathrm{O}_{\mathrm{v}}=0.71 \delta^{18} \mathrm{O}_{\mathrm{p}}-14.85, r=0.78, n=44\right.$, $p<0.01$ ), show similarities (Fig. 3).

Compared with the $\delta^{18} \mathrm{O}_{\mathrm{v}}$ values, the $\delta^{18} \mathrm{O}_{\mathrm{p}}$ values experienced significant relative enrichment at Nagqu in 2004 and 2005. Furthermore, the relative enrichment of $\delta^{18} \mathrm{O}_{\mathrm{p}}$ relative to $\delta^{18} \mathrm{O}_{\mathrm{v}}\left(\Delta \delta^{18} \mathrm{O}=\delta^{18} \mathrm{O}_{\mathrm{p}}-\delta^{18} \mathrm{O}_{\mathrm{v}}\right)$ in $2004(8.2 \%$ o $)$ was similar to that in $2005(8.2 \%$ ) (Fig. 2a and f), even though the sampling period in 2004 differed from that in 2005. The average relative enrichment at Nagqu in 2004 2005 was $8.2 \%$. 


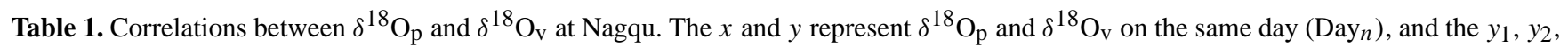
$y_{3}, \ldots$, and $y_{5}$ represent $\delta^{18} \mathrm{O}_{\mathrm{v}}$ in the following first day $\left(\mathrm{Day}_{n+1}\right), \ldots\left(\mathrm{Day}_{n+2}\right), \ldots\left(\mathrm{Day}_{n+3}\right), \ldots$, and the following fifth day $\left(\right.$ Day $\left._{n+5}\right)$, respectively.

\begin{tabular}{lrrrrrr}
\hline$\delta^{18} \mathrm{O}_{\mathrm{p}}-\delta^{18} \mathrm{O}_{\mathrm{v}}$ & Linear regression & Slope & $R^{2}$ & $r$ & $n$ & $p$ \\
\hline Day $_{n}-\mathrm{Day}_{n}$ & $y=0.72 x-14.5$ & 0.72 & 0.65 & 0.81 & 86 & $<0.01$ \\
$\mathrm{Day}_{n}-\mathrm{Day}_{n+1}$ & $y_{1}=0.61 x-16.4$ & 0.61 & 0.47 & 0.69 & 86 & $<0.01$ \\
$\mathrm{Day}_{n}-\mathrm{Day}_{n+2}$ & $y_{2}=0.62 x-15.9$ & 0.62 & 0.41 & 0.64 & 85 & $<0.01$ \\
$\mathrm{Day}_{n}-\mathrm{Day}_{n+3}$ & $y_{3}=0.57 x-16.7$ & 0.57 & 0.35 & 0.59 & 82 & $<0.01$ \\
$\mathrm{Day}_{n}-\mathrm{Day}_{n+4}$ & $y_{4}=0.38 x-20.2$ & 0.38 & 0.17 & 0.41 & 83 & $<0.01$ \\
Day $_{n}-\mathrm{Day}_{n+5}$ & $y_{5}=0.34 x-20.8$ & 0.34 & 0.12 & 0.35 & 85 & $<0.05$ \\
\hline
\end{tabular}

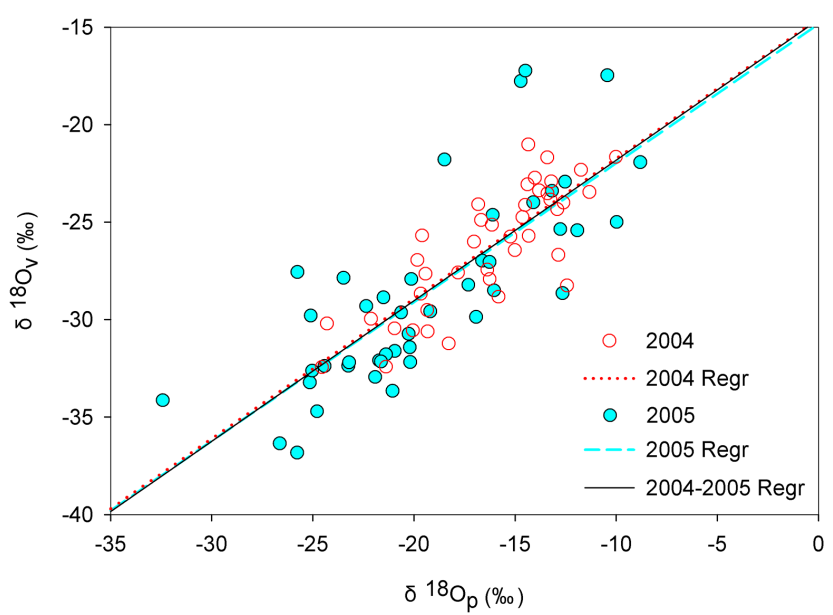

Figure 3. Relationships between $\delta^{18} \mathrm{O}_{\mathrm{p}}$ of precipitation and $\delta^{18} \mathrm{O}_{\mathrm{v}}$ of water vapour at Nagqu. Note that the values in 2004 are shown as red open circles; the values in 2005 are shown as blue solid dots.

\section{Discussion}

\subsection{Relationship between $\delta^{18} \mathrm{O}_{\mathrm{p}}$ of precipitation and $\delta^{18} \mathrm{O}_{\mathrm{v}}$ of water vapour}

In this study, the isotopic composition of precipitation correlated positively with that of water vapour. Similar close relationships between $\delta^{18} \mathrm{O}_{\mathrm{v}}$ and $\delta^{18} \mathrm{O}_{\mathrm{p}}$ also exist at Heidelberg (Jacob and Sonntag, 1991) and at Ankara (Dirican et al., 2005). During the process of precipitation, the $\delta^{18} \mathrm{O}$ values of water vapour are primarily influenced by isotopic equilibrium fractionation (Bonne et al., 2014). As the raindrop falls, the content of the raindrop contributes to the ambient water vapour, due to the re-evaporation effect. In that case, water vapour rapidly interacts with raindrops and tends to move toward isotopic equilibrium as the humid approaches to saturation (Deshpande et al., 2010). As a result, the isotopic composition of raindrops contributes to that of the ambient water vapour. Consequently, the isotopic composition of precipitation has a direct effect on the isotopic composition of water vapour. We show that the isotopic composition of precipitation affects that of water vapour, not only on the same day, but also for the next 4 days, resulting in correlation coefficients of $0.69,0.64,0.59$, and 0.41 (within a 0.01 confidence limit), respectively (Table 1). Clearly, the correlation coefficients and the slopes also decrease gradually over time, with the correlation coefficient for the fifth day decreasing even further (as low as 0.35 ) and correlated only within a 0.05 confidence limit (Table 1). Correspondingly, the slopes decreased gradually from 0.72 to 0.34 . This may partly be the result of surface water evaporation from recent precipitation contributing to the isotopic composition of the local water vapour in the days following the rainfall event. In addition, part of surface water vapour isotopes comes from local evapotranspiration that was affected by the previous precipitation. The decreasing correlations between the $\delta^{18} \mathrm{O}_{\mathrm{p}}$ and lagged $\delta^{18} \mathrm{O}_{\mathrm{v}}$ with time indicate that the contribution of the event precipitation to evaporation becomes smaller.

Clearly, there exists an interaction between the local evapotranspiration and boundary layer entrainment. Moreover, the boundary layer entrainment can interact with the water vapour in the high altitude, due to the intensive convection over the central Tibetan Plateau. Consequently, the local water vapour can have a part influence on the precipitation, via affecting the water vapour beneath the cloud base. Pfahl et al. (2012) found that microphysical interactions between rain drops and water vapour beneath the cloud base exist by using $\mathrm{COSMO}_{\text {iso }}$ model. As a result, the $\delta^{18} \mathrm{O}$ values of local water vapour in our study may have an indirect effect on those of precipitation.

\subsection{The relative enrichment of $\delta^{18} \mathrm{O}_{\mathrm{p}}$ relative to $\delta^{18} \mathrm{O}_{\mathrm{v}}$}

As reported above, the average relative enrichment of $\delta^{18} \mathrm{O}_{\mathrm{p}}$ relative to $\delta^{18} \mathrm{O}_{\mathrm{v}}$ in our study was $8.2 \%$. In comparison, the average relative enrichment of $\delta^{18} \mathrm{O}_{\mathrm{p}}$ relative to $\delta^{18} \mathrm{O}_{\mathrm{v}}$ at the Delingha station $\left(37^{\circ} 22^{\prime} \mathrm{N}, 97^{\circ} 22^{\prime} \mathrm{E}, 2981 \mathrm{~m}\right.$; see Fig. 1) on the northern Tibetan Plateau $\left(\Delta \delta^{18} \mathrm{O}=10.7 \%\right.$ ) (Yin et al., 2008) was higher. This is because Indian monsoon and convection activities at Nagqu are more intense when compared with those at Delingha. Due to the combined impact of these activities, the summer $\delta^{18} \mathrm{O}_{\mathrm{p}}$ values at Nagqu were more depleted than those at Delingha (Yu et al., 2008). As a conse- 
quence, the $\Delta \delta^{18} \mathrm{O}$ value at Nagqu fell below that at Delingha. Further south, the relative enrichment of $\delta^{18} \mathrm{O}_{\mathrm{p}}$ relative to $\delta^{18} \mathrm{O}_{\mathrm{v}}$ at the Bay of Bengal (Fig. 1) was $8.6 \%$ (Midhun et al., 2013), similar to that at Nagqu. While the Indian monsoon at the Bay of Bengal exceeds the intensity of that at Nagqu, the oceanic moisture does not rise to the same degree as at Nagqu. We note that the relative enrichment of $\delta^{18} \mathrm{O}_{\mathrm{p}}$ relative to $\delta^{18} \mathrm{O}_{\mathrm{v}}$ at the Nagqu station differs from that at the northern station (Delingha), but resembles that of the southern station (Bay of Bengal), apparently because of its unique location, which is affected by both the Indian monsoon and convection. The next section discusses the influences of those activities on water vapour/precipitation $\delta^{18} \mathrm{O}$ changes in detail.

\subsection{The effects of meteorological and environmental factors on $\delta^{18} \mathrm{O}$ of water vapour and precipitation}

A number of meteorological parameters affect the $\delta^{18} \mathrm{O}$ variations of water vapour and precipitation. In particular, different processes dominate the relative humidity variations in different regions, resulting in different isotope ratios in the water vapour (Noone, 2012). In general, water vapour $\delta^{18} \mathrm{O}$ is positively correlated with local surface humidity, consistent with Rayleigh distillation processes. The data from Palisades (USA) show that stable isotopic compositions of water vapour correlate positively with relative humidity (White and Gedzelman, 1984). Wen et al. (2010) also found a positive correlation between water vapour $\delta^{18} \mathrm{O}$ and relative humidity at Beijing (China). At a northern Greenland site, both diurnal and intra-seasonal variations show strong correlations between changes in local surface humidity and water vapour isotopic composition (Steen-Larsen et al., 2013). Bonne et al. (2014) also found a positive correlation between water vapour $\delta^{18} \mathrm{O}$ in southern Greenland and the logarithm of local surface humidity exists. In addition, water vapour $\delta^{18} \mathrm{O}$ trends from the Bermuda Islands (North Atlantic) also resemble those of relative humidity (Steen-Larsen et al., 2014). Apparently, those results are consistent with Rayleigh distillation in which air parcels become dry and isotopically depleted through condensation during air mass advection.

Interestingly, the tendencies of $\delta^{18} \mathrm{O}_{\mathrm{v}}$ and $\delta^{18} \mathrm{O}_{\mathrm{p}}$ in our study oppose those of relative humidity (Fig. 2). Hence, at Nagqu the $\delta^{18} \mathrm{O}$ values of water vapour and precipitation correlate negatively with relative humidity (RH) (Fig. 4b, Table 2). Moreover, the tendencies of $\delta^{18} \mathrm{O}_{\mathrm{v}}$ and $\delta^{18} \mathrm{O}_{\mathrm{p}}$ in our study clearly differed from those of surface temperature at $1.5 \mathrm{~m}$ or ground temperature at $0 \mathrm{~m}$ during the entire sampling period (Fig. 2). No positive correlation was found between the $\delta^{18} \mathrm{O}$ values and temperature (Fig. 4a, Table 2). Thus, the changes in the $\delta^{18} \mathrm{O}$ values of water vapour and precipitation did not depend on changes in temperature, and did not experience a "temperature effect". However, on the northern Tibetan Plateau, the $\delta^{18} \mathrm{O}$ composition of water vapour and precipitation correlated positively with tem-
Table 2. Correlations between stable oxygen isotope $\left(\delta^{18} \mathrm{O}_{\mathrm{v}}\right.$ and $\delta^{18} \mathrm{O}_{\mathrm{p}}$ ) and meteorological factors (temperature, relative humidity, surface pressure, and precipitation amount) at Nagqu.

\begin{tabular}{lrrrr}
\hline & Slope & $r$ & $n$ & $p$ \\
\hline$\delta^{18} \mathrm{O}_{\mathrm{v}}-T$ & -0.33 & -0.32 & 153 & $<0.01$ \\
$\delta^{18} \mathrm{O}_{\mathrm{p}}-T$ & -0.35 & -0.27 & 90 & $<0.01$ \\
$\delta^{18} \mathrm{O}_{\mathrm{v}}-\mathrm{RH}$ & -0.20 & -0.45 & 153 & $<0.01$ \\
$\delta^{18} \mathrm{O}_{\mathrm{p}}-\mathrm{RH}$ & -0.28 & -0.36 & 90 & $<0.01$ \\
$\delta^{18} \mathrm{O}_{\mathrm{v}}-\mathrm{Psfc}$ & 1.11 & 0.41 & 153 & $<0.01$ \\
$\delta^{18} \mathrm{O}_{\mathrm{p}}-\mathrm{Psfc}$ & 1.09 & 0.34 & 90 & $<0.01$ \\
$\delta^{18} \mathrm{O}_{\mathrm{v}}-P$ & -0.43 & -0.44 & 153 & $<0.01$ \\
$\delta^{18} \mathrm{O}_{\mathrm{p}}-P$ & -0.36 & -0.43 & 90 & $<0.01$ \\
\hline
\end{tabular}

perature (Yin et al., 2008). A positive correlation between the isotope record of water vapour and temperature $(T)$ was also found at Heidelberg (Germany), western Siberia, southern Greenland, and Minnesota (USA) (respectively, SchochFischer et al., 1984; Bastrikov et al., 2014; Bonne et al., 2014; Welp et al., 2008). Clearly, the relationships between $\delta^{18} \mathrm{O}-$ $T$ and $\delta^{18} \mathrm{O}-\mathrm{RH}$ at our station differ from those at other stations. This and the $\delta^{18} \mathrm{O}$ depletion during the summer monsoon period (Fig. 2a and f) may reflect the influences of the Indian monsoon (Yu et al., 2008) and increasing convection (Tremoy et al., 2012). Due to an uplift effect of the massive mountains (such as the Himalayas), warm oceanic moisture transported by the Indian monsoon from the Indian Ocean onto the Tibetan Plateau rises to very high elevations, where very low temperatures prevail (Tian et al., 2003; Yu et al., 2008). This rise results in more depleted $\delta^{18} \mathrm{O}$ values recorded in summertime water vapour and precipitation at Nagqu. Moreover, the intense convection raises the oceanic moisture to higher elevations. Hence, the convection effect for the oceanic moisture increases the more depleted $\delta^{18} \mathrm{O}$ in water vapour and precipitation in our study region (Yu et al., 2008). However, during the monsoon period, the corresponding surface air temperature, relative humidity, and the summer rainfall greatly exceed those during the pre-monsoon and post-monsoon periods (Fig. 2). Accordingly, an inverse correlation exists between $\delta^{18} \mathrm{O}$ in water vapour/precipitation and surface air temperatures, relative humidity, and rainfall, respectively, indicating the lack of a "temperature effect" on $\delta^{18} \mathrm{O}$ in water vapour/precipitation in this study region (Table 2). Particularly, mixing processes related to convection and reevaporation of rainfall over the central Tibetan Plateau play a significant role in controlling the water vapour distribution. That is why the $\delta^{18} \mathrm{O}$ values of water vapour over the central Tibetan Plateau deviate a Rayleigh model. Lee et al. (2011) also found the free tropospheric vapour over tropical oceans does not strictly follow a Rayleigh distillation.

Furthermore, the $\delta^{18} \mathrm{O}$ trends coincide with surface pressure (Psfc) during the entire sampling period (Figs. 2, 4c, Table 2). In particular, different pressures at a large spatial 

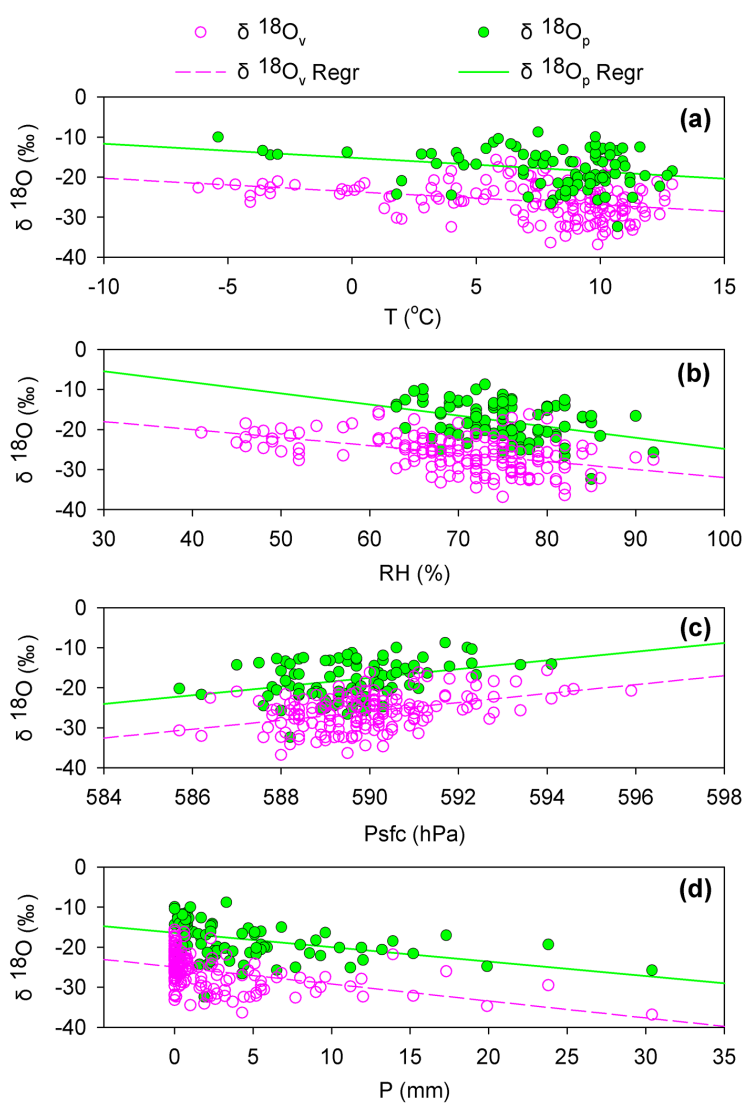

Figure 4. Relationships between $\delta^{18} \mathrm{O}$ and meteorological factors (a, temperature; b, relative humidity; c, surface pressure; and d, precipitation amount) at Nagqu. Note that the values of $\delta^{18} \mathrm{O}_{\mathrm{v}}$ are shown as pink open circles; the values of $\delta^{18} \mathrm{O}_{\mathrm{p}}$ are shown as green solid dots.

scale are associated with different weather systems and thus different moisture sources. For example, the low geopotential height at $500 \mathrm{hPa}$ on 6 August 2005 over the Nagqu station indicated that a low pressure system prevailed in the study region. However, a high pressure system was posed over the Bay of Bengal and the Arabian Sea (Fig. 5a). The marine moisture was transported to the Tibetan Plateau by the Indian monsoon. That is to say, the source vapour for precipitation is predominantly external to the study area in summer monsoon season. As a result, the $\delta^{18} \mathrm{O}$ values of water vapour and precipitation are as low as -32.1 and $-21.7 \%$, respectively (Fig. 2f). The corresponding precipitation amount was as high as $25.9 \mathrm{~mm}$ (Fig. 2j). In contrast, a high geopotential height at $500 \mathrm{hPa}$ was observed on 5 September 2005 over Nagqu. This indicates that the study region was controlled by the high pressure system and the coastal regions were dominated by a low pressure system, which relates to the westerlies and continental circulation (Fig. 5b). Hence, the $\delta^{18} \mathrm{O}$ values of water vapour and precipitation are as high as -17.5 and $-10.4 \%$, respectively (Fig. 2f). The corresponding precipitation amount is only $0.4 \mathrm{~mm}$ (Fig. $2 \mathrm{j}$ ).
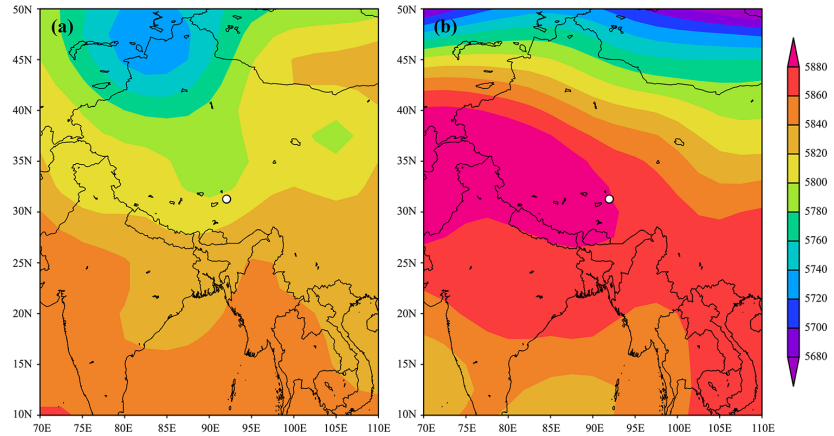

Figure 5. Distributions of the geopotential height (unit: meter) at $500 \mathrm{hPa}$ on 6 August (a) and 5 September (b) 2005 over the Tibetan Plateau and adjacent regions, representing the conditions of low pressure (a) and high pressure (b) over the Nagqu station (white dots).

High precipitation amounts correspond to depleted isotope compositions of water vapour and precipitation, and low precipitation amounts correspond to enriched isotope compositions (Fig. 2). Specifically, the isotope compositions of water vapour exhibit relatively high values, during non-rainy periods $(P$ [precipitation amount] $=0)($ Fig. $2 \mathrm{a}, \mathrm{f}, \mathrm{e}$ and $\mathrm{j})$. During non-rainy periods, climate type is considered as the main factor that dominates the temporal variability of the $\delta^{18} \mathrm{O}$ values of water vapour. This demonstrates that precipitation amount also affects the $\delta^{18} \mathrm{O}$ variations of water vapour and precipitation at Nagqu (Fig. 4c, Table 2). During precipitation events, the water vapour generally maintains a state of equilibrium with falling raindrops (Lee et al., 2006). During heavy precipitation events, the isotope ratios of water vapour and condensate decrease as saturated air rises, because of continued fractionation during condensation (Gedzelman and Lawrence, 1982), and the $\delta^{18} \mathrm{O}$ values of precipitation tend to become more depleted (Fig. 2a and f). Correspondingly, heavily depleted $\delta^{18} \mathrm{O}$ values of residual water vapour occur, due to the rainout effect. During periods without precipitation, water vapour dominated by the local evapotranspiration deviates far from saturation, i.e., it may exhibit low relative humidity. In these circumstances, the $\delta^{18} \mathrm{O}$ values of water vapour become highly enriched (Fig. 2a and f). Okazaki et al. (2015) also found that the main driver of the more depleted $\delta^{18} \mathrm{O}_{\mathrm{v}}$ from Niamey was a larger amount of precipitation at the Guinea coast.

To further reveal the relationships between the $\delta^{18} \mathrm{O}$ values and various meteorological parameters, our study modeled $\delta^{18} \mathrm{O}$ as a function of temperature, relative humidity, surface pressure, and precipitation amount, using a simple multiple regression model. Using a stepwise method and based on the output of this model, the variable of temperature was excluded. The function can be expressed as: 
$\delta^{18} \mathrm{O}_{\mathrm{v}}=-502.80-0.11 \mathrm{RH}+0.82 \mathrm{Psfc}-0.28 P$

( $p$ for RH, Psfc, and $P$ is $0.001,0.000,0.000$, respectively;

$\left.F=28.276, F_{\alpha}=5.709, F>F_{\alpha}, \alpha=0.001\right)$

$\delta^{18} \mathrm{O}_{\mathrm{p}}=-580.66-0.18 \mathrm{RH}+0.98 \mathrm{Psfc}-0.26 P$

( $p$ for RH, Psfc, and $P$ is $0.022,0.001,0.002$, respectively;

$\left.F=15.249, F_{\alpha}=5.932, F>F_{\alpha}, \alpha=0.001\right)$.

The multiple correlation coefficients $(R)$ between all of the independent variables (relative humidity, surface pressure, and precipitation amount) and the dependent variables $\left(\delta^{18} \mathrm{O}_{\mathrm{v}}\right.$ and $\left.\delta^{18} \mathrm{O}_{\mathrm{p}}\right)$ are 0.60 and 0.56 ; and the $F$ statistics are significant at the 0.001 and 0.001 levels, respectively. In brief, the $\delta^{18} \mathrm{O}$ changes in water vapour and precipitation at Nagqu relate closely to the joint contributions of relative humidity, pressure, and precipitation amount.

In addition, land surface characteristics and processes such as evaporation and transpiration may also have affected the isotopic ratios of water vapour. During dry periods, the land surface dries due to evapotranspiration, and the moisture in soil and grass (characterized by relatively enriched isotopic values) evaporates into the atmosphere. Therefore, the isotopic ratio of water vapour becomes relatively enriched (Fig. 2a and f). That is why the isotope compositions of water vapour become more enriched during days with no rainfall, compared to during days with rainfall. During heavy rain events, however, local evapotranspiration is extremely weak (Huang and Wen, 2014), because clouds and precipitation cool the surface and moisten the boundary layer, leading to high relative humidities (Fig. 2c and h) (Aemisegger et al., 2014). Therefore, effects of local evapotranspiration on the changes in water vapour $\delta^{18} \mathrm{O}$ can be ignored during such rainy periods, and the corresponding $\delta^{18} \mathrm{O}$ values in water vapour become more depleted (Fig. 2a and f). On cessation of the rain, clouds clear, the ground heats up again, and relative humidity decreases, partly due to warming, partly due to reduced humidity (Aemisegger et al., 2014). In this case, local evapotranspiration will contribute to changes in water vapour $\delta^{18} \mathrm{O}$, which will quickly return to relatively enriched values (Fig. 2a and f) (Deshpande et al., 2010). Another short-term study by Kurita et al. (2008), undertaken not far from this study area, also demonstrated that water vapour increased gradually, accompanied by an increased contribution of evapo-transpired water that had relatively enriched isotopic values.

\section{4 $\delta^{18} \mathrm{O}$ changes in water vapour and precipitation related to different moisture sources}

Synoptic weather circulation (especially moisture sources) strongly affects the variations of stable isotopic compositions of water vapour and precipitation (Strong et al., 2007; Pfahl and Wernli, 2008; Deshpande et al., 2010; Guan et al.,
2013). This study used the NOAA HYSPLIT model to calculate $120 \mathrm{~h}$ back trajectories of air parcels for each day of the entire sampling period. Figure 6 shows a subset of the results of the atmospheric trajectories. The results of 12 July, 6 August, 26 August, and 5 September 2005, represent the weak monsoon, the active monsoon, the late monsoon, and the post-monsoon period conditions, respectively. During the weak monsoon period, moisture over Nagqu at $1000 \mathrm{~m}$ a.g.l. appears to derive predominantly from the coastal regions of Bengal in the south, which might have been transported earlier by the Indian monsoon and lingered there. In this way, the coastal regions of Bengal act as a moisture reservoir during the weak monsoon period. Clearly, moisture from 2000 and $3000 \mathrm{~m}$ a.g.l. recycles from the westerlies (which are associated with enriched surface waters that re-evaporate and with evaporated surface water under lower humidity conditions), and this contributes to the moisture over Nagqu during the weak monsoon period (Fig. 6a). Therefore, $\delta^{18} \mathrm{O}_{\mathrm{v}}$ and $\delta^{18} \mathrm{O}_{\mathrm{p}}$ values show relative enrichment (such as -17.8 and $-14.7 \%$ observed on 12 July 2005) (Fig. 2f).

Compared to the weak monsoon period (Fig. 6a), the contribution of moisture from the westerlies and regional circulation decreased during the active monsoon period (Fig. 6b) (the specific humidity fells to $2 \mathrm{~g} \mathrm{~kg}^{-1}$ over Nagqu). Due to the dominant Indian monsoon circulation during this period, most moisture at the $1000 \mathrm{~m}$ a.g.l. of the trajectories came from this direction. As a result, specific humidity over Nagqu from this pathway increased to $7 \mathrm{~g} \mathrm{~kg}^{-1}$ (Fig. 6b). In addition, the trajectories of the $2000 \mathrm{~m}$ a.g.l. airflow came from the southern slope of the Himalayas (Fig. 6b). The moisture from both of those two paths was uplifted by the high mountains. Moreover, convection over the Tibetan Plateau often occurs in the region between the two major east-west mountain ranges, the Nyainqentanglha Mountains and the northern Himalayas (Fujinami et al., 2005). As mentioned above, intense convection over the Tibetan Plateau, combined with uplift caused by the high mountains, causes oceanic moisture to rise to very high elevations. Obviously, convection of marine and continental air masses not only causes isotopic variations of water vapour (Farlin et al., 2013), but also significantly affects the isotopic composition of the precipitation (Risi et al., 2008). In particular, the time period when convection significantly affects the isotopic composition of precipitation relates to the residence time of water within atmospheric reservoirs (Risi et al., 2008). This results in more depleted $\delta^{18} \mathrm{O}$ values of water vapour and precipitation at Nagqu, such as -32.1 and $-21.7 \%$ on 6 August 2005 (Fig. 2f). The corresponding maximum precipitation amount of $25.9 \mathrm{~mm}$ over Nagqu was observed during this sampling period in 2005 (Fig. 2j). Purushothaman et al. (2014) also reported the highly depleted nature of water vapour at Roorkee (northern India) during rainy periods, due to the intense Indian monsoon.

Although moisture over Nagqu that derived from the Bay of Bengal decreased during the late monsoon period, some of 

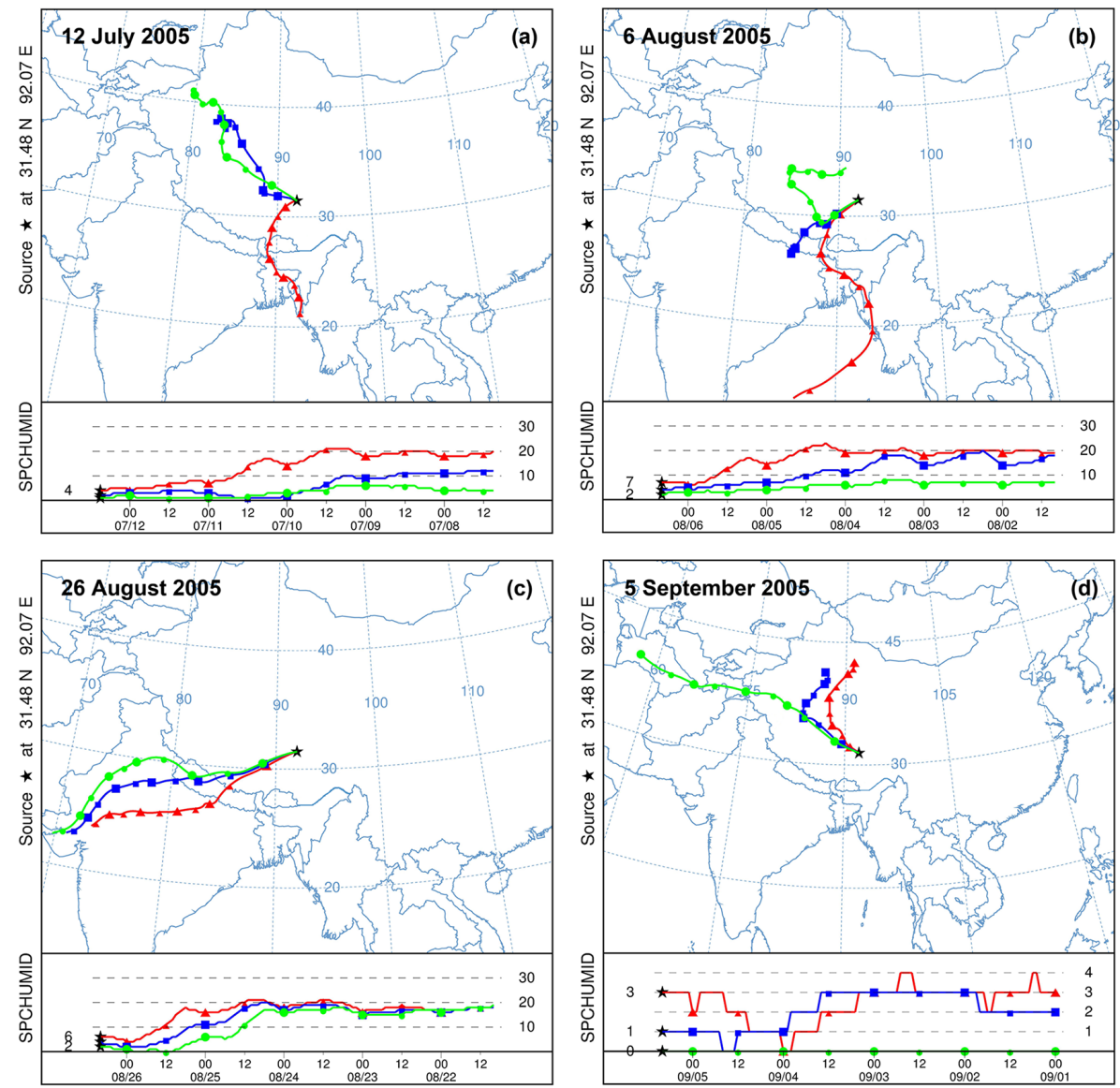

Figure 6. Back trajectories calculated by HYSPLT at 1000 (red lines), 2000 (blue lines), and 3000 m (green lines) a.g.l. on 12 July, 6 August, 26 August, and 5 September 2005, representing the conditions during the weak monsoon (a), active monsoon (b), late monsoon (c), and postmonsoon (d) periods, respectively, over the Nagqu station. Note that changes in specific humidity $\left(\mathrm{g} \mathrm{kg}^{-1}\right)$ along the air parcel pathways are also shown.

the trajectories continued to originate in the coastal regions. Figure 6c details one selected event on 26 August 2005, during which the trajectories came from the coastal regions of western India (near the Arabian Sea). The specific humidity over Nagqu from those pathways decreased to 2$6 \mathrm{~g} \mathrm{~kg}^{-1}$, compared with those during the active monsoon period. Moisture from those paths was uplifted by the high mountains, via the Indian continent, and also contributed to the relatively depleted $\delta^{18} \mathrm{O}$ values of water vapour and precipitation (-32.6, $-25.0 \%$ ) (Fig. 2f).

Trajectories after the rainy season (such as 5 September 2005, accompanying the Indian monsoon retreat) show that all the moisture had been recycled from the continent (Purushothaman et al., 2014): (1) moisture from the regional circulation dominated the moisture sources in the study area, and (2) moisture from the westerlies also affected the Nagqu region (Fig. 6d). During this period, no contributions from the Bay of Bengal or the coastal regions of Bengal/western India appeared to have significantly enriched $\delta^{18} \mathrm{O}$ values of water vapour (such as $-17.5 \%$ on 5 September 2005)
(Fig. 2f). During the dry season, specific humidity over Nagqu from those pathways decreased below $3 \mathrm{~g} \mathrm{~kg}^{-1}$, and isotopic re-equilibration of rain droplets with surrounding water vapour appear to have affected the $\delta^{18} \mathrm{O}$ variations of precipitation (Sturm et al., 2007). Consequently, the $\delta^{18} \mathrm{O}$ values of precipitation increased rapidly during the postmonsoon period (to $-10.4 \%$ ) (Fig. 2f).

\subsection{Implication of $\delta^{18} \mathrm{O}$ in water vapour and precipitation for paleoclimatic records}

Our study indicates that, during the summer period, moisture over the Nagqu region of the central Tibetan Plateau originates primarily from the southern portion of the Tibetan Plateau, as well as the southern slope of the Himalayas, the coastal regions of Bengal/western India, and the Bay of Bengal, all strongly influenced by the Indian monsoon and convection. In contrast, convection on the northern Tibetan Plateau is weaker than that on the central Tibetan Plateau, and the westerlies prevail on the northern Tibetan Plateau, almost without any influence of the Indian monsoon (Tian 
et al., 2003; Yu et al., 2008). That is to say, different sampling locations result in different moisture sources, resulting in different climate information preserved in ice cores. In particular, different moisture sources cause different effects on the $\delta^{18} \mathrm{O}$ values of water vapour and precipitation at the two stations of Nagqu and Delingha, located on the central and northern Tibetan Plateau, respectively. This results in different $\delta^{18} \mathrm{O}$ characteristics of water vapour and precipitation from the central and northern Tibetan Plateau and may explain the different $\delta^{18} \mathrm{O}$ characteristics of ice cores from the central and northern Tibetan Plateau. In the northern Tibetan Plateau, due to the moisture sources being fairly simple, isotopic fractions in ice cores from the northern Tibetan Plateau have not been changed by many of the factors discussed here, and the $\delta^{18} \mathrm{O}$ records can be used as a good proxy of temperature. For example, the $\delta^{18} \mathrm{O}$ record preserved in the Dunde ice core from the northern Tibetan Plateau provides a reasonable proxy of summer temperature (Thompson et al., 1989). However, the interpretations of ice core records is more complicated than that in the northern Tibetan Plateau, because of the various moisture sources on the central Tibetan Plateau, especially during the period of the intensive Indian monsoon activities. As a result, the $\delta^{18} \mathrm{O}$ record in the Tanggula ice core from the central Tibetan Plateau shows no correlation between average $\delta^{18} \mathrm{O}$ values and temperature (Joswiak et al., 2010). Accordingly, our findings indicate that the influences of different moisture sources and the activities of the Indian monsoon and convection may be significant when reconstructing paleoclimate variations on the central and northern Tibetan Plateau. Certainly, ice core (or other proxy) $\delta^{18} \mathrm{O}$ records do not reflect day-to-day changes of $\delta^{18} \mathrm{O}$ in water vapour/precipitation. In order to disprove the presence of a temperature effect over the central Tibetan Plateau, multiple years of data and data that span the entire year will be needed for future studies. Hence, the authors have launched a new project to survey a longer time series of isotopic compositions of water vapour and precipitation $\left(\delta^{18} \mathrm{O}\right.$ and $\left.\delta \mathrm{D}\right)$, which should provide greater confidence in our findings and gain a better understanding of the links between water vapour and precipitation $\delta^{18} \mathrm{O} / \delta \mathrm{D}$ values and paleoclimatic records.

\section{Conclusions}

This study represents the first simultaneous water vapour and precipitation $\delta^{18} \mathrm{O}$ time series for the central Tibetan Plateau. In the study region of Nagqu, the isotopic composition of precipitation has a direct relationship to that of water vapour. In comparison, the $\delta^{18} \mathrm{O}$ values of local water vapour may only partly contribute to those of precipitation. The $\delta^{18} \mathrm{O}_{\mathrm{v}}$ and $\delta^{18} \mathrm{O}_{\mathrm{p}}$ variations at Nagqu appear mainly controlled by joint influences of relative humidity, pressure, and precipitation amount, but did not demonstrate a "temperature effect". Moreover, the different $\delta^{18} \mathrm{O}$ characteristics of water vapour and precipitation at Nagqu appear to relate to different mois- ture sources, especially involving the influences of the Indian monsoon and convection. The relative enrichment of $\delta^{18} \mathrm{O}_{\mathrm{p}}$ relative to $\delta^{18} \mathrm{O}_{\mathrm{v}}$ at Nagqu (on the central Tibetan Plateau) is similar to that at the southern station (Bay of Bengal), but differs from that at the northern station (Delingha), due to intense Indian monsoon and convection activities. These results may explain the different $\delta^{18} \mathrm{O}$ characteristics obtained from ice cores from the central and the northern Tibetan Plateau. Our findings presented here may provide a basis for reinterpretation of the $\delta^{18} \mathrm{O}$ records in ice cores from the central Tibetan Plateau, and suggest that the impacts of different moisture sources, the Indian monsoon, and convection activities all need to be considered.

Acknowledgements. This work was supported by CAS (Grant No. XDB03030100) and NSFC (Grant Nos. 91437110, 41125003, and 41371086). Special thanks are given to the three anonymous reviewers for their constructive comments. The authors would like to thank Changliang Yin, Guangcai Chen, and the staff from the Nagqu Meteorological Station for helping with fieldwork. The authors gratefully acknowledge the NOAA Air Resources Laboratory (ARL) for providing the HYSPLIT transport model (http://ready.arl.noaa.gov/HYSPLIT.php) used in this publication and NCEP reanalysis derived data provided by the NOAA/OAR/ESRL PSD, Boulder, Colorado, USA (ftp://arlftp.arlhq.noaa.gov/pub/archives/reanalysis). Some meteorological data were provided by the Climatic Data Center, National Meteorological Information Center, China Meteorological Administration.

Edited by: J. P. Huang

\section{References}

Aemisegger, F., Pfahl, S., Sodemann, H., Lehner, I., Seneviratne, S. I., and Wernli, H.: Deuterium excess as a proxy for continental moisture recycling and plant transpiration, Atmos. Chem. Phys., 14, 4029-4054, doi:10.5194/acp-14-4029-2014, 2014.

Aizen, V., Aizen, E., Melack, J., and Martma, T.: Isotopic measurements of precipitation on central Asian glaciers (southeastern Tibet, northern Himalayas, central Tien Shan), J. Geophys. Res., 101, 9185-9196, 1996.

An, Z., Kutzbach, J. E., Prell, W. L., and Porter, S. C.: Evolution of Asian monsoons and phased uplift of the Himalaya-Tibetan Plateau since Late Miocene times, Nature, 411, 62-66, 2001.

Angert, A., Lee, J.-E., and Yakir, D.: Seasonal variations in the isotopic composition of near-surface water vapour in the eastern Mediterranean, Tellus B, 60, 674-684, 2008.

Araguás-Araguás, L., Froehlich, K., and Rozanski, K.: Stable isotope composition of precipitation over southeast Asia, J. Geophys. Res., 103, 28721-28742, 1998.

Bastrikov, V., Steen-Larsen, H. C., Masson-Delmotte, V., Gribanov, K., Cattani, O., Jouzel, J., and Zakharov, V.: Continuous measurements of atmospheric water vapour isotopes in western Siberia (Kourovka), Atmos. Meas. Tech., 7, 1763-1776, doi:10.5194/amt-7-1763-2014, 2014. 
Bershaw, J., Penny, S. M., and Garzione, C. N.: Stable isotopes of modern water across the Himalaya and eastern Tibetan Plateau: Implications for estimates of paleoelevation and paleoclimate, J. Geophys. Res., 117, D02110, doi:10.1029/2011JD016132, 2012.

Bonne, J.-L., Masson-Delmotte, V., Cattani, O., Delmotte, M., Risi, C., Sodemann, H., and Steen-Larsen, H. C.: The isotopic composition of water vapour and precipitation in Ivittuut, southern Greenland, Atmos. Chem. Phys., 14, 4419-4439, doi:10.5194/acp-14-4419-2014, 2014.

Breitenbach, S. F. M., Adkins, J. F., Meyer, H., Marwan, N., Kumar, K. K., and Haug, G. H.: Strong influence of water vapor source dynamics on stable isotopes in precipitation observed in Southern Meghalaya, NE India, Earth Planet. Sci. Lett., 292, 212-220, 2010.

Bryson, R. A.: Airstream climatology of Asia, in: Proceedings of the International Symposium on the Qinghai-Xizang Plateau and Mountain Meteorology, March 20-24, 1984, Beijing, China, edited by: Xu, Y. G., American Meteorological Society, Boston, 604-617, 1986.

Cai, Y., Cheng, H., An, Z., Edwards, R. L., Wang, X., Tan, L., and Wang, J.: Large variations of oxygen isotopes in precipitation over south-central Tibet during Marine Isotope Stage 5, Geology, 38, 243-246, 2010.

Dansgaard, W.: Stable isotopes in precipitation, Tellus, 16, 436468, 1964.

Deshpande, R. D., Maurya, A. S., Kumar, B., Sarkar, A., and Gupta, S. K.: Rain-vapor interaction and vapor source identification using stable isotopes from semiarid western India, J. Geophys. Res., 115, D23311, doi:10.1029/2010JD014458, 2010.

Dirican, A., Ünal, S., Acar, Y., and Demircan, M.: The temporal and seasonal variation of $\mathrm{H}-2$ and $\mathrm{O}-18$ in atmospheric water vapour and precipitation from Ankara, Turkey in relation to air mass trajectories at Mediterranean basin, in: Isotopic Composition of Precipitation in the Mediterranean Basin in Relation to Air Circulation Patterns and Climate, IAEA, Vienna, 191-214, 2005.

Draxler, R. R. and Rolph, G. D.: An overview of the HYSPLIT_4 modelling system for trajectories, dispersion, and deposition, Aust. Meteorol. Mag., 47, 295-308, 1998.

Farlin, J., Lai, C.-T., and Yoshimura, K.: Influence of synoptic weather events on the isotopic composition of atmospheric moisture in a coastal city of the western United States, Water Resour. Res., 49, 3685-3696, 2013.

Fujinami, H., Nomura, S., and Yasunari, T.: Characteristics of diurnal variations in convection and precipitation over the southern Tibetan Plateau during summer, SOLA, 1, 49-52, 2005.

Gat, J. R., Klein, B., Kushnir, Y., Roether, W., Wernli, H., Yam, R., and Shemesh, A.: Isotope composition of air moisture over the Mediterranean Sea: an index of the air-sea interaction pattern, Tellus B, 55, 953-965, 2003.

Gedzelman, S. D. and Lawrence, J. R.: The isotopic composition of cyclonic precipitation, J. Appl. Meteorol., 21, 1385-1404, 1982.

Guan, H., Zhang, X., Skrzypek, G., Sun, Z., and Xu, X.: Deuterium excess variations of rainfall events in a coastal area of South Australia and its relationship with synoptic weather systems and atmospheric moisture sources, J. Geophys. Res., 118, 1123-1138, 2013.
Huang, L. and Wen, X.: Temporal variations of atmospheric water vapor $\delta \mathrm{D}$ and $\delta^{18} \mathrm{O}$ above an arid artificial oasis cropland in the Heihe River Basin, J. Geophys. Res., 119, 11456-11476, 2014.

Hübner, H., Kowski, P., Hermichen, W.-D., Richter, W., and Schütze, T.: Regional and temporal variations of deuterium in the precipitation and atmospheric moisture of central Europe, Isotope Hydrology 1978, Vienna/Austria: IAEA-publications, 289307, 1979.

Iannone, R. Q., Romanini, D., Cattani, O., Meijer, H. A. J., and Kerstel, E. R. T.: Water isotope ratio $\left(\delta^{2} \mathrm{H}\right.$ and $\left.\delta^{18} \mathrm{O}\right)$ measurements in atmospheric moisture using an optical feedback cavity enhanced absorption laser spectrometer, J. Geophys. Res., 115, D10111, doi:10.1029/2009JD012895, 2010.

Jacob, H. and Sonntag, C.: An 8-vear record of the seasonal variation of ${ }^{2} \mathrm{H}$ and ${ }^{18} \mathrm{O}$ in atmospheric water vapour and precipitation at Heidelberg, Germany, Tellus B, 43, 291-300, 1991.

Joswiak, D. R., Yao, T., Wu, G., Xu, B., and Zheng, W.: A 70-yr record of oxygen-18 variability in an ice core from the Tanggula Mountains, central Tibetan Plateau, Clim. Past, 6, 219-227, doi:10.5194/cp-6-219-2010, 2010.

Jouzel, J. and Merlivat, L.: Deuterium and oxygen 18 in precipitation: modeling of the isotopic effects during snow formation, J. Geophys. Res., 89, 11749-11757, 1984.

Kurita, N. and Yamada, H.: The role of local moisture recycling evaluated using stable isotope data from over the middle of the Tibetan Plateau during the monsoon season, J. Hydrometeorol., 9, 760-775, 2008.

Lai, C.-T., Ehleringer, J. R., Bond, B. J., and Paw, U. K. T.: Contributions of evaporation, isotopic non-steady state transpiration and atmospheric mixing on the $\delta^{18} \mathrm{O}$ of water vapour in Pacific Northwest coniferous forests, Plant Cell Environ., 29, 77-94, 2006.

Lee, J., Worden, J., Noone, D., Bowman, K., Eldering, A., LeGrande, A., Li, J.-L. F., Schmidt, G., and Sodemann, H.: Relating tropical ocean clouds to moist processes using water vapor isotope measurements, Atmos. Chem. Phys., 11, 741-752, doi:10.5194/acp-11-741-2011, 2011.

Lee, X., Sergeant, S., Smith, R., and Tanner, B.: In situ measurement of the water vapor ${ }^{18} \mathrm{O} /{ }^{16} \mathrm{O}$ isotope ratio for atmospheric and ecological applications, J. Atmos. Ocean. Tech., 22, 555-565, 2005.

Lee, X., Smith, R., and Williams, J.: Water vapour ${ }^{18} \mathrm{O} /{ }^{16} \mathrm{O}$ isotope ratio in surface air in New England, USA, Tellus B, 58, 293-304, 2006.

Liu, J., Song, X., Yuan, G., Sun, X., and Yang, L.: Stable isotopic compositions of precipitation in China, Tellus B, 66, 22567, doi:10.3402/tellusb.v66.22567, 2014.

Liu, X., Xu, G., Grießinger, J., An, W., Wang, W., Zeng, X., Wu, G., and Qin, D.: A shift in cloud cover over the southeastern Tibetan Plateau since 1600: evidence from regional tree-ring $\delta^{18} \mathrm{O}$ and its linkages to tropical oceans, Quaternary Sci. Rev., 88, 55-68, 2014.

Midhun, M., Lekshmy, P. R., and Ramesh, R.: Hydrogen and oxygen isotopic compositions of water vapor over the Bay of Bengal during monsoon, Geophys. Res. Lett., 40, 6324-6328, 2013.

Noone, D.: Pairing measurements of the water vapor isotope ratio with humidity to deduce atmospheric moistening and dehydration in the tropical midtroposphere, J. Climate, 25, 4476-4494, 2012. 
Okazaki, A., Satoh, Y., Tremoy, G., Vimeux, F., Scheepmaker, R., and Yoshimura, K.: Interannual variability of isotopic composition in water vapor over western Africa and its relationship to ENSO, Atmos. Chem. Phys., 15, 3193-3204, doi:10.5194/acp15-3193-2015, 2015.

Pang, H., Hou, S., Kaspari, S., and Mayewski, P. A.: Influence of regional precipitation patterns on stable isotopes in ice cores from the central Himalayas, The Cryosphere, 8, 289-301, doi:10.5194/tc-8-289-2014, 2014.

Pfahl, S. and Wernli, H.: Air parcel trajectory analysis of stable isotopes in water vapor in the eastern Mediterranean, J. Geophys. Res., 113, D20104, doi:10.1029/2008JD009839, 2008.

Pfahl, S., Wernli, H., and Yoshimura, K.: The isotopic composition of precipitation from a winter storm - a case study with the limited-area model COSMOiso, Atmos. Chem. Phys., 12, 16291648, doi:10.5194/acp-12-1629-2012, 2012.

Posmentier, E. S., Feng, X., and Zhao, M.: Seasonal variations of precipitation $\delta^{18} \mathrm{O}$ in eastern Asia, J. Geophys. Res., 109, D23106, doi:10.1029/2004JD004510, 2004.

Purushothaman, P., Rao, M. S., Kumar, B., Rawat, Y. S., Krishan, G., and Devi, P.: Comparison of two methods for ground level vapour sampling and influence of meteorological parameters on its stable isotopic composition at Roorkee, India, Hydrol. Process., 28, 882-894, 2014.

Risi, C., Bony, S., and Vimeux, F.: Influence of convective processes on the isotopic composition $\left(\delta^{18} \mathrm{O}\right.$ and $\left.\delta \mathrm{D}\right)$ of precipitation and water vapor in the tropics: 2 . Physical interpretation of the amount effect, J. Geophys. Res., 113, D19306, doi:10.1029/2008JD009943, 2008.

Rozanski, K., Araguás-Araguás, L., and Gonfiantini, R.: Relation between long-term trends of oxygen-18 isotope composition of precipitation and climate, Science, 258, 981-985, 1992.

Schoch-Fischer, H., Rozanski, K., Jacob, H., Sonntag, C., Jouzel, I., Östlund, G., and Geyh, M. A.: Hydrometeorological factors controlling the time variation of $\mathrm{D},{ }^{18} \mathrm{O}$ and ${ }^{3} \mathrm{H}$ in atmospheric water vapour and precipitation in the northern westwind belt, in: Isotope Hydrology 1983, IAEA-publications, Vienna/Austria, 330, 1984.

Steen-Larsen, H. C., Johnsen, S. J., Masson-Delmotte, V., Stenni, B., Risi, C., Sodemann, H., Balslev-Clausen, D., Blunier, T., Dahl-Jensen, D., Ellehøj, M. D., Falourd, S., Grindsted, A., Gkinis, V., Jouzel, J., Popp, T., Sheldon, S., Simonsen, S. B., Sjolte, J., Steffensen, J. P., Sperlich, P., Sveinbjörnsdóttir, A. E., Vinther, B. M., and White, J. W. C.: Continuous monitoring of summer surface water vapor isotopic composition above the Greenland Ice Sheet, Atmos. Chem. Phys., 13, 4815-4828, doi:10.5194/acp-13-4815-2013, 2013.

Steen-Larsen, H. C., Sveinbjörnsdottir, A. E., Peters, A. J., MassonDelmotte, V., Guishard, M. P., Hsiao, G., Jouzel, J., Noone, D., Warren, J. K., and White, J. W. C.: Climatic controls on water vapor deuterium excess in the marine boundary layer of the North Atlantic based on 500 days of in situ, continuous measurements, Atmos. Chem. Phys., 14, 7741-7756, doi:10.5194/acp-14-77412014, 2014.

Strong, M., Sharp, Z. D., and Gutzler, D. S.: Diagnosing moisture transport using D / H ratios of water vapor, Geophys. Res. Lett., 34, L03404, doi:10.1029/2006GL028307, 2007.

Sturm, C., Hoffmann, G., and Langmann, B.: Simulation of the stable water isotopes in precipitation over South America: Compar- ing regional to global circulation models, J. Climate, 20, 37303750, 2007.

Thompson, L. G., Mosley-Thompson, E., Davis, M. E., Bolzan, J. F., Dai, J., Yao, T., Gundestrup, N., Wu, X., Klein, L., and Xie, Z.: Holocene-late Pleistocence climatic ice core records from Qinghai-Tibetan Plateau, Science, 246, 474-477, 1989.

Thompson, L. G., Yao, T., Mosley-Thompson, E., Davis, M. E., Henderson, K. A., and Lin, P.-N.: A high-resolution millennial record of the South Asian Monsoon from Himalayan ice cores, Science, 289, 1916-1919, 2000.

Tian, L., Masson-Delmotte, V., Stievenard, M., Yao, T., and Jouzel, J.: Tibetan Plateau summer monsoon northward extent revealed by measurements of water stable isotopes, J. Geophys. Res., 106, 28081-28088, 2001.

Tian, L., Yao, T., Schuster, P. F., White, J. W. C., Ichiyanagi, K., Pendall, E., Pu, J., and Yu, W.: Oxygen-18 concentrations in recent precipitation and ice cores on the Tibetan Plateau, J. Geophys. Res., 108, 4293, doi:10.1029/2002JD002173, 2003.

Tremoy, G., Vimeux, F., Mayaki, S., Souley, I., Cattani, O., Risi, C., Favreau, G., and Oi, M.: A 1-year long $\delta^{18} \mathrm{O}$ record of water vapor in Niamey (Niger) reveals insightful atmospheric processes at different timescales, Geophys. Res. Lett., 39, L08805, doi:10.1029/2012GL051298, 2012.

Treydte, K. S., Schleser, G. H., Helle, G., Frank, D. C., Winiger, M., Haug, G. H., and Esper, J.: The twentieth century was the wettest period in northern Pakistan over the past millennium, Nature, 440, 1179-1182, 2006.

Vuille, M., Werner, M., Bradley, R. S., and Keimig, F.: Stable isotopes in precipitation in the Asian monsoon region, J. Geophys. Res., 110, D23108, doi:10.1029/2005JD006022, 2005.

Welp, L. R., Lee, X., Kim, K., Griffis, T. J., Billmark, K. A., and Baker, J. M.: $\delta^{18} \mathrm{O}$ of water vapor, evapotranspiration and the sites of leaf water evaporation in a soybean canopy, Plant Cell Environ., 31, 1214-1228, 2008.

Wen, X.-F., Zhang, S.-C., Sun, X.-M., Yu, G.-R., and Lee, X.: Water vapor and precipitation isotope ratios in Beijing, China, J. Geophys. Res., 115, D01103, doi:10.1029/2009JD012408, 2010.

White, J. W. C. and Gedzelman, S. D.: The isotopic composition of atmospheric water vapor and the concurrent meteorological conditions, J. Geophys. Res., 89, 4937-4939, 1984.

Yao, T., Masson-Delmotte, V., Gao, J., Yu, W., Yang, X., Risi, C., Sturm, C., Werner, M., Zhao, H., He, Y., Ren, W., Tian, L., Shi, C., and Hou, S.: A review of climatic controls on $\delta^{18} \mathrm{O}$ in precipitation over the Tibetan Plateau: Observations and simulations, Rev. Geophys., 51, 525-548, 2013.

Yatagai, A., Sugimoto, A., and Nakawo, M.: The isotopic composition of water vapor and the concurrent meteorological conditions around the northeast part of the Tibetan Plateau, in: Proceedings for the 6th Int'1 Study Conference on GEWEX in Asia and GAME, 3-5 December 2004, Kyoto, Japan, 2-33, 2004.

Yin, C., Yao, T., Tian, L., Liu, D., Yu, W., and Qu, D.: Temporal variations of $\delta^{18} \mathrm{O}$ of atmospheric water vapor at Delingha, Sci. China Ser. D, 51, 966-975, 2008.

Yu, W., Yao, T., Tian, L., Wang, Y., and Yin, C.: Isotopic composition of atmospheric water vapor before and after the monsoon's end in the Nagqu River Basin, Chinese Sci. Bull., 50, 2755-2760, 2005.

Yu, W., Yao, T., Tian, L., Ma, Y., Ichiyanagi, K., Wang, Y., and Sun, $\mathrm{W}$. Relationships between $\delta^{18} \mathrm{O}$ in precipitation and air temper- 
ature and moisture origin on a south-north transect of the Tibetan Plateau, Atmos. Res., 87, 158-169, 2008.

Yu, W., Yao, T., Lewis, S., Tian, L., Ma, Y., Xu, B., and Qu, D.: Stable oxygen isotope differences between the areas to the north and south of Qinling Mountains in China reveal different moisture sources, Int. J. Climatol., 34, 1760-1772, 2014a.

Yu, W., Xu, B., Lai, C.-T., Ma, Y., Tian, L., Qu, D., and Zhu, Z.: Influences of relative humidity and Indian monsoon precipitation on leaf water stable isotopes from the southeastern Tibetan Plateau, Geophys. Res. Lett., 41, 7746-7753, 2014 b.

Yuan, F., Sheng, Y., Yao, T., Fan, C., Li, J., Zhao, H., and Lei, Y.: Evaporative enrichment of oxygen-18 and deuterium in lake waters on the Tibetan Plateau, J. Paleolimnol., 46, 291-307, 2011.
Zech, M., Tuthorn, M., Zech, R., Schlütz, F., Zech, W., and Glaser, B.: A $16-\mathrm{ka} \delta^{18} \mathrm{O}$ record of lacustrine sugar biomarkers from the High Himalaya reflects Indian Summer Monsoon variability, J. Paleolimnol., 51, 241-251, 2014.

Zhao, L., Xiao, H., Zhou, J., Wang, L., Cheng, G., Zhou, M., Yin, L., and Matthew, F. M.: Detailed assessment of isotope ratio infrared spectroscopy and isotope ratio mass spectrometry for the stable isotope analysis of plant and soil waters, Rapid Commun. Mass Sp., 25, 3071-3082, 2011. 